\title{
Memory B lymphocytes from secondary lymphoid organs interact with E-selectin through a novel glycoprotein ligand
}

\author{
María C. Montoya, ${ }^{1}$ Karin Holtmann, ${ }^{2}$ Karen R. Snapp, ${ }^{3}$ Eric Borges, ${ }^{2}$ \\ Francisco Sánchez-Madrid, ${ }^{1}$ Francis W. Luscinskas, ${ }^{4}$ Geoffrey Kansas, ${ }^{3}$ \\ Dietmar Vestweber, ${ }^{2}$ and Manuel O. de Landázuri ${ }^{1}$
}

${ }^{1}$ Servicio de Inmunología, Hospital de la Princesa, Universidad Autónoma de Madrid, Madrid 28006, Spain

${ }^{2}$ Institute of Cell Biology, ZMBE, University of Muenster, Technologiehof, Muenster D-48149, Germany

${ }^{3}$ Department of Microbiology-Immunology, Northwestern Medical School,

Chicago, Illinois 60611, USA

${ }^{4}$ Vascular Research Division, Department of Pathology, Brigham and Women's Hospital and Harvard Medical School,

Boston, Massachusetts 02160, USA

Address correspondence to: Manuel O. de Landázuri, Servicio de Inmunología,

Hospital de la Princesa, Diego de Leon 62, Madrid 28006, Spain. Phone: 34-91-4023347; Fax: 34-91-3092496;

E-mail: molandazuri/princesa@hup.es

Received for publication July 24, 1998, and accepted in revised form March 23, 1999.

\begin{abstract}
Recirculation of B lymphocytes through the secondary lymphoid organs is key for recognition and response to foreign antigen. B lymphocytes within secondary lymphoid organs comprise a heterogeneous population of cells at distinct differentiation stages. To ascribe a particular adhesive behavior to discrete B-cell subsets within secondary lymphoid organs, we investigated their functional interaction with endothelial selectins under flow. We describe herein the characterization of a subset of human tonsillar $\mathrm{B}$ cells that interact with E-selectin but not P-selectin. E-selectin-interacting B cells had a phenotype of non-germinal center $\left(\mathrm{CD}^{-} 0^{-}, \mathrm{CD} 38^{-}, \mathrm{CD} 44^{+}\right)$, memory $\left(\mathrm{IgD}^{-}\right)$cells. Furthermore, FucT-VII was expressed selectively in $\mathrm{CD}_{4} 4^{+}$E-selectin-adherent B lymphocytes. B-cell rolling on E-selectin required sialic acid but was independent of previously described selectin ligands. A novel glycoprotein ligand of $240 \mathrm{kDa}$ carrying $\mathrm{N}$-linked glycans was isolated from B-cell membranes by an E-selectin immunoadhesin. Binding of this protein was strictly $\mathrm{Ca}^{2+}$ dependent, was inhibited by a cell adhesion-blocking mAb against Eselectin, and required the presence of sialic acid but not $\mathrm{N}$-linked carbohydrates. Our results enable us to assign to resident memory B lymphocytes a novel adhesion function, the rolling on E-selectin, that provides insights on the adhesion pathways involved in homing of memory B cells to tertiary sites.
\end{abstract}

J. Clin. Invest. 103:1317-1327 (1999).

\section{Introduction}

B lymphocytes continuously recirculate through the blood and secondary lymphoid organs, such as peripheral lymph nodes, spleen, Peyer's patches, or tonsils, thus allowing them to encounter and react to antigen localized at these sites. Naive B cells enter the tonsils and will either continue the recirculation surveillance process in case they do not encounter antigen, or they will specifically recognize and respond to antigen located in the tonsils. B cells that encounter antigen become activated and undergo clonal expansion and somatic hypermutation that leads to differentiation into memory and plasma cells $(1,2)$. These cells return to the circulation, and some are directed to tertiary sites where they will exert their effector functions (3). B cells within secondary lymphoid organs can thus be classified, depending on their differentiation stage, into discrete subpopulations that are located at different compartments within these organs. B-cell subpopulations, including naive, germinal center (GC), memory, or plasma cells, can be phenotypically characterized by their differential expression of several cell surface markers (1).

The selectin family of adhesion molecules has been classically implicated in the initial steps of the interac- tion of lymphocytes with the endothelium during lymphocyte homing. L-selectin, expressed by most circulating lymphocytes, is the principal receptor implicated in the interaction of lymphocytes with high endothelial venules (HEV), which is the first step for their entry into secondary lymphoid organs. This molecule also mediates lymphocyte recruitment to inflammatory sites (4). P-selectin, expressed by platelets and endothelial cells shortly after activation with inflammatory mediators, has been implicated in early leukocyte rolling during the inflammatory response (4). E-selectin is also an inducible endothelial adhesion molecule, although its expression follows slower kinetics, reaching its maximum level after 4-6 hours of stimulation with inflammatory mediators. This molecule is involved in leukocyte rolling during acute and chronic inflammation $(5,6)$. Moreover, E-selectin has been found in endothelium undergoing proliferation and tube formation, thus implicating this molecule in angiogenesis $(7,8)$. Thus, the role of E-selectin is not restricted to mediating leukocyte-endothelial interactions during inflammation. Accordingly, constitutive expression of E-selectin has been reported at low levels in venules of tonsils, adenoids, skin, and hematopoietic tissues (9-13). Further- 
a

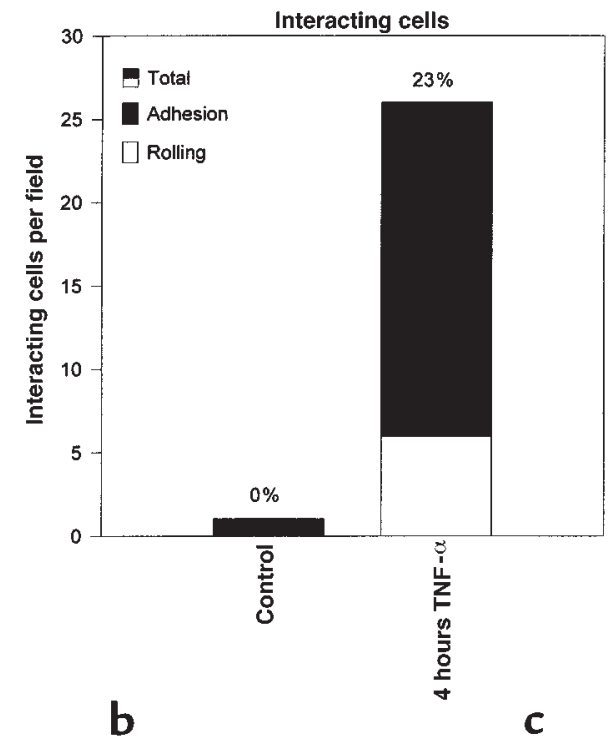

Endothelial treatments

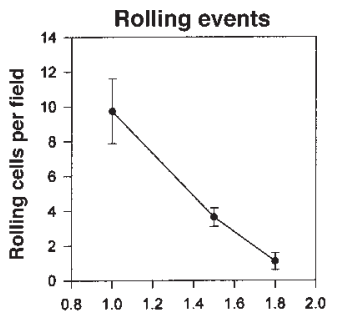

Estimated shear stress $\left(\right.$ dyn $/ \mathrm{cm}^{2}$ )

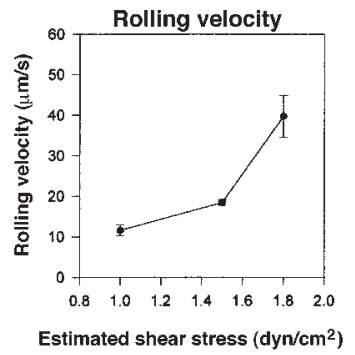

Figure 1

Adhesion of B lymphocytes to HUVEC monolayers under defined laminar flow conditions. Confluent HUVEC monolayers grown on glass coverslips were activated or not (control) with TNF- $\alpha$ for 4 hours, and then the coverslips were inserted in a parallel-plate flow chamber. B lymphocytes were perfused through the chamber at an estimated wall shear stress of 1 dyn $/ \mathrm{cm}^{2}(0.54 \mathrm{~mL} / \mathrm{min})(\mathbf{a})$, or B cells were perfused across 4-hour TNF$\alpha$-activated HUVEC monolayers at $1,1.5$, or $1.8 \mathrm{dyn} / \mathrm{cm}^{2}$ (b and $\mathbf{c}$ ). The number of rolling and adherent cells per field of view was determined by analysis of videotapes as described in Methods. Values represent the average number of interacting cells $(\mathbf{a})$, arithmetic mean \pm SEM number of rolling cells (b), or rolling velocity (c) calculated from 3 independent experiments after 5 minutes of perfusion at each level of flow.

more, expression of E-selectin has been reported on the surface of astrocytes and hepatocytes $(14,15)$.

Carbohydrate structures, such as $\mathrm{Le}^{\mathrm{x}}$, $\mathrm{sLe}^{\mathrm{x}}$, or Le $\mathrm{L}^{\mathrm{a}}$, decorate glycoproteins that have been identified as the highaffinity selectin ligands. Expression of functional selectin ligands requires the action of $\alpha(1,3)$-fucosyltransferases (FucTs). Several of these enzymes have been described, although only FucT-IV and -VII have been involved in the synthesis of E-selectin ligands in leukocytes (4). Mucin-like glycoprotein ligands of selectins were identified by affinity isolation using antibody-like selectin fusion proteins. P-selectin glycoprotein ligand1 (PSGL-1) was first identified as a P-selectin ligand (16, $17)$, although it has also been reported to bind E-selectin $(16,18)$ and L-selectin $(19-21)$. This molecule mediates rolling on P-selectin (19-22), but it is unable to mediate rolling on E-selectin on certain cell types $(22,23)$. More- over, L-selectin has recently been proposed as a highaffinity ligand for E-selectin $(24,25)$. Other E-selectinbinding proteins have been identified, including Eselectin ligand-1 (ESL-1), which was described in myeloid cells as a $150-\mathrm{kDa}$ glycoprotein binding via $\mathrm{N}$ linked oligosaccharides to E-selectin $(26,27)$. A 250-kDa glycoprotein on bovine $\gamma / \delta$ T cells was described as a new E-selectin ligand $(24,28)$.

Several studies have addressed the presence of selectin ligands on B cells. We reported previously that in vitro-activated tonsillar B cells interact with E- and Pselectin under static conditions (29). More recently, Yago et al. (30) showed that peripheral blood (PB) B cells bind well to P-selectin, but not to E-selectin, under flow conditions. To our knowledge, the present work provides the first evidence that a subset of tonsillar B cells interacts with E-selectin under defined laminar flow conditions. This functional approach has allowed us to ascribe a novel adhesive behavior to the subset of resident memory B cells from secondary lymphoid organs. Furthermore, the B-cell rolling on E-selectin was not mediated by any of the previously identified E-selectin ligands. Using a recombinant antibody-like form of E-selectin, we have found a novel functional ligand of $240 \mathrm{kDa}$ for $\mathrm{E}-$ selectin on tonsillar B cells.

\section{Methods}

Cells and cell cultures. Human tonsillar B cells were obtained from 4- to 12-year-old children undergoing routine tonsillectomy, as described previously (29). Mononuclear cells were isolated by Ficoll-Hypaque density gradients and enriched with B cells by rosetting with sheep erythrocytes (Biomerieux, MarcyL'Etoile, France) treated with 2-aminoethyl-isothiouronium bromide (AET) (Sigma Chemical Co., St. Louis, Missouri, USA). The resulting B cell-enriched population was $>98 \%$ $\mathrm{CD} 19^{+}$and $<2 \% \mathrm{CD}^{+}$. $\mathrm{CD} 44^{+}$and $\mathrm{CD} 38^{+} \mathrm{B}$-cell populations were isolated by negative selection with immunomagnetic beads (MACS; Miltenyi Biotec, Bergisch Gladbach, Germany) and resulted $>98 \%$ pure.

Human umbilical vein endothelial cells (HUVECs) were isolated, pooled, and grown in M199 culture medium supplemented with $10 \%$ FCS endothelial cell growth factor (25 $\mu \mathrm{g} / \mathrm{mL})$ and porcine intestinal heparin $(50 \mu \mathrm{g} / \mathrm{mL}$; Sigma Chemical Co.). HUVEC monolayers were treated with or without $25 \mathrm{ng} / \mathrm{mL}$ of recombinant human TNF- $\alpha$. Chinese hamster ovary (CHO) cells expressing a stably transfected human E- or P-selectin cDNA (CHO-E or CHO-P, respectively) were grown in Alpha media (GIBCO BRL, Paisley, Scotland, United Kingdom) containing $10 \%$ dialyzed FCS (dFCS) as detailed previously (31). A parental cell line (CHO-DUKX) was also grown in Alpha media with $10 \%$ dFCS supplemented with (-)-adenosine (Sigma-Aldrich, Steinheim, Germany) and 2'-deoxyadenosine and thymidine (Sigma Chemical Co.). These cell lines were generously provided by R.T. Camphausen (Genetics Institute, Cambridge, Massachusetts, USA).

Antibodies and immunofluorescent staining of B cells. Blocking mAb's anti-human E-selectin (H18/7) (32), anti-P-selectin (HDPG 2/3) (17), and anti-PSGL-1 (KPL-1) (21) were used as purified IgGs. Polyclonal, affinity-purified antibodies from rabbit antisera 89060 raised against ESL/IgG ( $\alpha$ ESL-1) or control antibodies obtained from the same serum purified on human IgG1 were described elsewhere (27). Blocking antibody antimouse E-selectin (UZ4) or control antibody recognizing the $\mathrm{Fc}$ region of human IgG1 (28AG10) were described elsewhere (33, 34). The mAb's anti-CD5 and anti-CD10 were obtained from Becton Dickinson Immunocytometry Systems (San Jose, Cali- 
fornia, USA). HC1/1 mAb (anti- $\alpha \mathrm{x}$ ), TS1/11 (anti- $\alpha \mathrm{L}$ ), HP2/1 (anti- $\alpha 4$ ), TS1/18 (anti- $\beta 2$ ), TS2/16 (anti- $\beta 1$ ), SAM-1 (anti- $\alpha 5$ ), $16 \mathrm{BDH}$ (anti-CD38), HP2/9 (anti-CD44), and BU38 (antiCD23) have been described previously $(29,35)$. The following mAb's were kindly provided by different investigators: anti-VCAM-1 (4B9) (36) (J.M. Harlan, University of Washington, Seattle, Washington, USA); anti-CD19 (BU12) (G.D. Johnson, University of Birmingham, Birmingham, United Kingdom); anti-CLA (HECA-452) (6) (E.C. Butcher, Stanford University, Palo Alto, California, USA); anti-sLe ${ }^{\mathrm{x}}$ (CSLEX) (P.I Terasaki, University of California-Los Angeles, Los Angeles, California, USA) (37); SNH3, FH6, 2H5, and 2F3 (R. Kannagi, Aichi Cancer Center, Nagoya, Japan) (38, 39); anti-PSGL-1 (PSL 275) (31) (R.T. Camphausen); and L-selectin (LAM 1/3) (40) (T.F. Tedder, Duke University, Durham, North Carolina, USA). Anti-HLA class I (W6/32) was used as a binding, nonblocking control, and murine P3X63 was used as a nonbinding negative control. Surface expression of adhesion molecules was studied by flow cytometry analyses as described previously $(29,41)$. Briefly, cells previously treated with human $\gamma$-globulin were incubated with the primary $\mathrm{mAb}$ at $4^{\circ} \mathrm{C}$ for 15 minutes, and FITC-conjugated goat anti-mouse $\mathrm{F}\left(\mathrm{ab}^{\prime}\right)_{2}$ (DAKO A/S, Glostrup, Denmark) was used as secondary $\mathrm{mAb}$. The fluorescence of 2,000 cells was measured on a FACScan (Becton Dickinson Immunocytometry Systems), and the data are presented as mean fluorescence intensity and cell number. For two-color immunofluorescence analysis, phycoerythrin-conjugated goat anti-mouse $\mathrm{F}\left(\mathrm{ab}^{\prime}\right)_{2}$ (DAKO A/S) was used as secondary mAb. Anti-IgD-FITC was obtained from PharMingen (San Diego, California, USA). Fluorescence of 6,000 cells was measured. FL-1 and FL-2 mean fluorescence intensities are represented as contour plots.

The following reagents were used for immunoprecipitation assays. The E-selectin/IgG fusion protein has been described (42). This protein contains the $4 \mathrm{NH}_{2}$-terminal domains of mouse E-selectin (lectin, EGF, and the first 2 complement binding domains) fused to the $\mathrm{Fc}$ part (hinge, $\mathrm{C} 1$, and $\mathrm{C} 2$ domains) of human IgG1. Vascular endothelial-cadherin (VE-cadherin)/IgG fusion protein has been described elsewhere (43). Rabbit anti-ESL-1 antiserum 89060 was raised against an ESL/IgG fusion protein and affinity purified as described (27). Rabbit anti-PSGL-1 antiserum 703 was raised against a $\mathrm{COOH}$-terminal peptide of human PSGL-1 (44). The mAb H130 against human CD45 was obtained from PharMingen (San Diego, California, USA), and the mAb 68 against Hsp90 that cross-reacts with mouse Hsp90 was obtained from Transduction Laboratories (Lexington, Kentucky, USA).

Lymphocyte adhesion assays. The parallel-plate flow chamber used for leukocyte adhesion under defined laminar flow has been described in detail (41). Briefly, the chamber consists of 2 stainless steel plates separated by a silastic gasket. The flow-field dimensions are $5 \mathrm{~mm}$ wide $\times 30 \mathrm{~mm}$ long $\times 0.250 \mathrm{~mm}$ high. Confluent endothelial or $\mathrm{CHO}$ cells grown on circular 25-mm glass coverslips (Fisher Scientific Inc., Medford, Massachusetts, USA) were placed in the flow chamber. Defined flow levels were applied by drawing media containing B lymphocytes $\left(10^{6} / \mathrm{mL}\right)$ through the chamber using a syringe pump (model 44; Harvard Apparatus Inc., Natick, Massachusetts, USA). Temperature was maintained at $37^{\circ} \mathrm{C}$ by heating plates. The flow apparatus was mounted on a Nikon Diaphot inverted microscope (Nikon, Toyko, Japan), and the entire perfusion period (6 minutes for each condition) was recorded on videotape by a video camera and video cassette recorder. B cells were considered to be adherent after 20 seconds of stable contact with the monolayer. B-cell rolling was easily viewed, as these cells travel more slowly than free-flowing ones. The number of rolling cells was calculated in 4 different fields at each time point of every independent experiment. Rolling velocities were calculated using an automated $\mathrm{PC}$-based image analysis software program (OPTIMAS; Bioscan Inc., Edmonds,
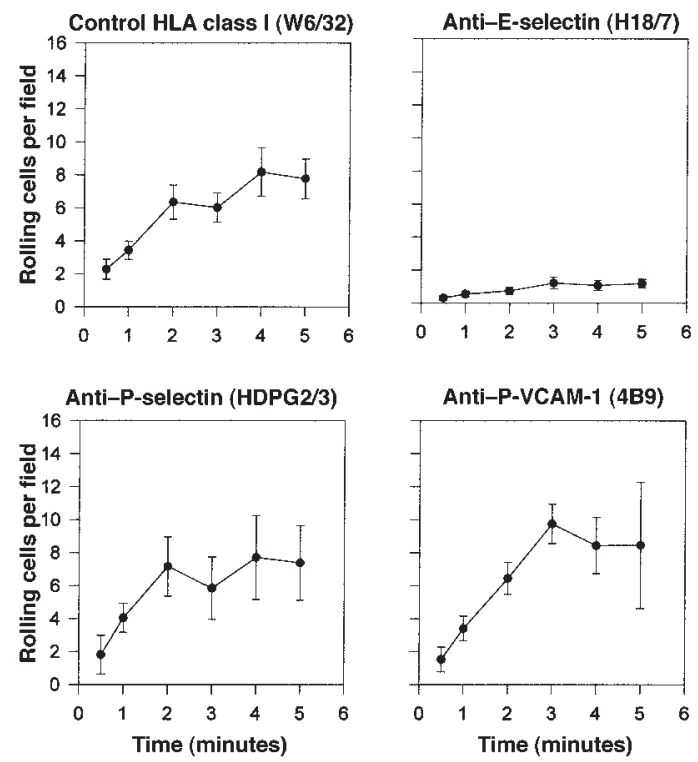

\section{Figure 2}

B-lymphocyte rolling on activated endothelium is mediated by E-selectin. Four-hour TNF- $\alpha$-activated HUVEC monolayers were grown on glass coverslips and treated for 20 minutes at room temperature with $10 \mu \mathrm{g} / \mathrm{mL}$ of $m A b$ directed to HLA class I (W6/32), E-selectin (H18/7), P-selectin (HDPG 2/3), or VCAM-1 (4B9); then the coverslip was assembled in a parallel-plate flow chamber. B cells were perfused across the HUVEC monolayers at an estimated shear stress of $1 \mathrm{dyn} / \mathrm{cm}^{2}$ for 5 minutes, and the number of rolling cells was determined in 4 separate fields at the different time points of each independent experiment. Values represent arithmetic means \pm SEM number of rolling cells calculated from 3 independent experiments.

Washington, USA). For antibody blocking studies, B cells, HUVECs, or CHO monolayers were incubated for 20 minutes with $10 \mu \mathrm{g} / \mathrm{mL}$ of the indicated antibody, and the assay was carried out without removal of the antibody.

Adhesion assays under rotation conditions were performed on 6-well plates previously coated with confluent CHO monolayers. Plates were placed on a shaker under rotation conditions of $72 \mathrm{rpm}$ and $1.5 \times 10^{7} \mathrm{~B}$ cells were added to each well. After 15 minutes of incubation, wells were washed with PBS to remove unbound cells, and then adherent cells were removed by adding $1 \mathrm{~mL}$ of $0.5 \mathrm{mM}$ EDTA in PBS.

Enzymatic treatment of B cells. For sialidase treatment, B cells $\left(10^{7}\right)$ were washed, resuspended in $1 \mathrm{~mL}$ of RPMI-1640, and then incubated for 1 hour at $37^{\circ} \mathrm{C}$ with neuraminidase (Boehringer Mannheim Biochemicals, Indianapolis, Indiana, USA) derived from Vibrio cholerae at $0.1 \mathrm{U} / \mathrm{mL}$. As control, another sample was incubated at the same conditions without neuraminidase. For $O$-sialoglycoprotein endopeptidase (OSGE; Accurate Chemicals, Westbury, New York, USA) treatment, B lymphocytes were washed in Dulbecco's phosphate-buffered saline (DPBS) and resuspended at $10^{7}$ cells $/ \mathrm{mL}$ in DPBS containing $20 \mathrm{mM}$ HEPES, $0.2 \% \mathrm{FCS}$, and $0.5 \mathrm{mM} \mathrm{Ca}^{2+}$ and $\mathrm{Mg}^{2+}$. Digestion with OSGE $(40 \mu \mathrm{g} / \mathrm{mL})$ was carried out for 1 hour at $37^{\circ} \mathrm{C}$. Mock treatment was done under identical conditions in the absence of this enzyme.

Immunoprecipitation. B cells isolated from human tonsils (3.5 $\times 10^{7}$ cells) were washed 3 times in PBS and surface biotinylated in $1 \mathrm{~mL}$ PBS containing $0.5 \mathrm{mg} / \mathrm{mL}$ Sulfo-NHS-Biotin (Pierce Chemical Co., Rockford, Illinois, USA) for 30 minutes on ice. The reaction was blocked by incubating the cells for 10 minutes in $1 \mathrm{~mL}$ DMEM (GIBCO BRL) without FCS on ice. Cells were washed with PBS twice and subjected to immuno- 

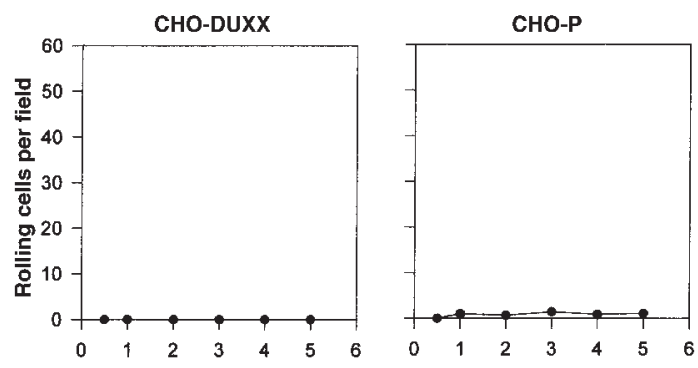

CHO-E (anti-HLA class II)

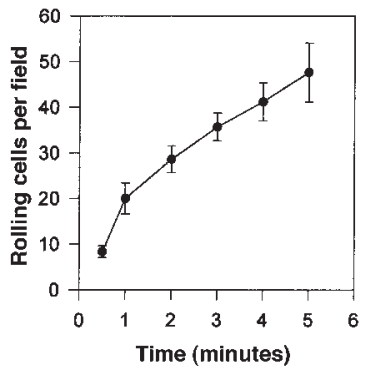

CHO-E (anti-E-selectin)

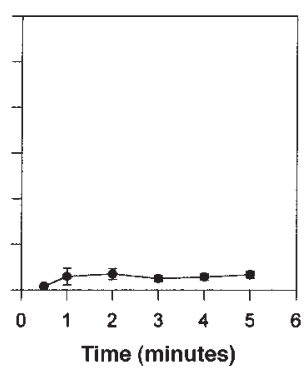

Figure 3

E-selectin, but not P-selectin, transfectants support rolling of B lymphocytes. CHO-DUKX, CHO-P, and $\mathrm{CHO}-\mathrm{E}$ monolayers were grown on glass coverslips. The latter were treated for 20 minutes with $10 \mu \mathrm{g} / \mathrm{mL}$ of mAb directed to HLA class I (W6/32) or E-selectin (H18/7). B cells were then perfused across the monolayers for 5 minutes at $1 \mathrm{dyn} / \mathrm{cm}^{2}$. The number of rolling cells was calculated as the mean of 4 different fields at every time point of each independent experiment. Values represent arithmetic mean \pm SEM number of rolling cells calculated from 3 independent experiments.

precipitation performed as described (26). Briefly, an aliquot of the cell detergent extract corresponding to $10^{7} \mathrm{~B}$ cells was incubated with $20 \mu \mathrm{L}$ protein A-Sepharose loaded with $5 \mu \mathrm{g}$ antibody, E-selectin/IgG, or VE-cadherin/IgG fusion protein. For blocking experiments, the protein A-Sepharose coupled to Eselectin/IgG was further incubated for 12 hours with $400 \mu \mathrm{g}$ of UZ4 or 28AG6. Mouse mAb's were bound to protein ASepharose by rabbit anti-mouse IgG and incubated with an aliquot of cell lysate corresponding to $5 \times 10^{6} \mathrm{~B}$ cells. The same amount of cell lysate was used for the immunoprecipitations using rabbit antibodies. Immunoprecipitated proteins were separated by electrophoresis on 6\% SDS-PAGE and transferred to nitrocellulose (Schleicher \& Schüll, Dassel, Germany). Filters were analyzed for biotinylated proteins with peroxidase-conjugated streptavidin (Dianova, Hamburg, Germany) and an enhanced chemiluminescence (ECL) system (Amersham Life Sciences Inc., Arlington Heights, Illinois, USA).

Endoglycosidase F treatment of the E-selectin ligand. The $240-\mathrm{kDa}$ $\mathrm{E}$-selectin ligand was affinity isolated from biotin-labeled tonsilar B lymphocytes as already described here, and it was eluted with $10 \mathrm{mM}$ EDTA, $150 \mathrm{mM} \mathrm{NaCl}$, and $0.05 \%$ Triton X-100. A total of $20 \mu \mathrm{L}$ of the EDTA eluate corresponding to $5 \times 10^{6} \mathrm{cells}$ was set aside for PAGE; $60 \mu \mathrm{L}$ of the eluate corresponding to 15 $\times 10^{6}$ cells was digested with $0.5 \mathrm{U}(10 \mu \mathrm{L})$ of endoglycosidase F (Boehringer Mannheim GmbH, Mannheim, Germany) for 12 hours at $37^{\circ} \mathrm{C}$. Mock treatment was done under identical conditions in the absence of the enzyme. One third of the digest or mock-treated sample was set aside for PAGE, while the remaining two thirds were again incubated with E-selectin/IgG protein A-Sepharose in the presence of $20 \mathrm{mM} \mathrm{CaCl}_{2}$ for 3 hours and then washed and eluted with EDTA as already described here. Semiquantitative RT-PCR and Southern blot analysis. Total cellular RNA was isolated from $10^{7}$ cells, using Trizol (GIBCO BRL) according to the manufacturer's instructions. Reverse transcription of $1 \mu \mathrm{g}$ of DNase-treated total cellular RNA was carried out as described previously $(21,45)$. PCR reactions containing $5 \mu \mathrm{L}$ of the appropriate $\mathrm{RT}$ reaction in a final reaction volume of $100 \mu \mathrm{L}$ containing $1.5 \mathrm{mM} \mathrm{MgCl}_{2}, 0.2 \mathrm{mM}$ each dNTP, $0.5 \mathrm{mM}$ specific sense and antisense primers, and $2.5 \mathrm{U}$ Taq polymerase (Perkin-Elmer Corp., Norwalk, Connecticut, USA) were carried out with cycle parameters as follows: 1 minute at $94^{\circ} \mathrm{C}, 1$ minute at $65^{\circ} \mathrm{C}$, and 1 minute at $72^{\circ} \mathrm{C}$, for 35 cycles (FucT-VII), 25 cycles (pgk1), or 30 cycles (C2GnT and FucT-IV). Primers were as follows: for detection of FucT-VII mRNA, sense 5'-CCC ACC GTG GCC CAG TAC CGC TTC T-3' and antisense 5'-CTG ACC TCT GTG CCC AGC CTC CCG T-3'; for FucT-IV detection, sense 5'-CGG GTG TGC CAG GCT GTA CAG AGG$3^{\prime}$ and antisense 5'-TCG GGA ACA GTT GTG TAT GAG ATT3'; for C2GnT detection, sense 5'-TTT TCW GGC AGT GCC TAC TTC GTG GTC and antisense 5'-ATG CTC ATC CAA ACA CTG GAT GGC AAA; for pgk1 detection, sense 5'-ATG ATT ATT GGT GGT GGA ATG GCT-3' ${ }^{\prime}$ and antisense $5^{\prime}$-TCA TCC ATG AGA GCT TTG GTT CC-3'. FucT-VII primers amplified a product of 500 bp; FucT-IV, a product 480 bp; pgk1, a product $374 \mathrm{bp}$; and C2GnT, a product $372 \mathrm{bp}$. Presence of PCR products was assayed by gel electrophoresis in $1.4 \%$ agarose. DNA was transferred onto nitrocellulose in 10× SSC, and Southern blotting of the RT-PCR products was carried out using randomprimed probes as described previously $(21,45)$.

\section{Results}

E-selectin-mediated rolling of tonsillar B lymphocytes on endothelium. To investigate whether different B-cell subpopulations in secondary lymphoid organs can be distinguished based on their differential selectin-mediated cell interactions, we performed adhesion assays of purified nonactivated tonsillar B cells to HUVECs under flow conditions. Very few adhesive contacts took place between B cells and the control unactivated HUVEC monolayer. In contrast, many resting tonsillar B cells were able to contact, roll, and subsequently arrest on 4-hour TNF- $\alpha$-activated HUVEC monolayers. Examination of B cells in contact with the endothelium after 5 minutes of perfusion

Table 1

Expression of adhesion molecules in the total and E-selectin-adherent subpopulations of B cells

\begin{tabular}{|c|c|c|c|c|c|c|c|c|c|c|c|c|c|c|}
\hline & \multicolumn{2}{|c|}{$\alpha \mathrm{L}$} & \multicolumn{2}{|c|}{$\beta 2$} & \multicolumn{2}{|c|}{$\alpha 4$} & \multicolumn{2}{|c|}{$\alpha 5$} & \multicolumn{2}{|c|}{$\beta 1$} & \multicolumn{2}{|c|}{$\alpha x$} & \multicolumn{2}{|c|}{ L-selectin } \\
\hline & $\%+$ & $\mathrm{mfi}$ & $\%+$ & $\mathrm{mfi}$ & $\%+$ & $\mathrm{mfi}$ & $\%^{+}$ & $\mathrm{mfi}$ & $\%+$ & $\mathrm{mfi}$ & $\%+$ & $\mathrm{mfi}$ & $\%+$ & $\mathrm{mfi}$ \\
\hline Total & 99.6 & 48.6 & 99.8 & 61.3 & 28.7 & 9.11 & 31.9 & 9.58 & 57.1 & 14.5 & 6.65 & 7.76 & 20.5 & 10.9 \\
\hline Adherent & 99.7 & 54.5 & 99.6 & 69.6 & 54.9 & 19.4 & 52.7 & 18.7 & 73.0 & 23.7 & 31.9 & 12.8 & 49.4 & 52.1 \\
\hline
\end{tabular}

Purified tonsillar B cells were allowed to attach to $\mathrm{CHO}-\mathrm{E}$-coated wells under rotation conditions. Then wells were washed, and adherent cells were collected as described in Methods. Expression of different adhesion molecules was analyzed by flow cytometry. Percentage of positive cells $(\%+)$ and mean fluorescence intensity (mfi) are represented for 1 representative experiment. 


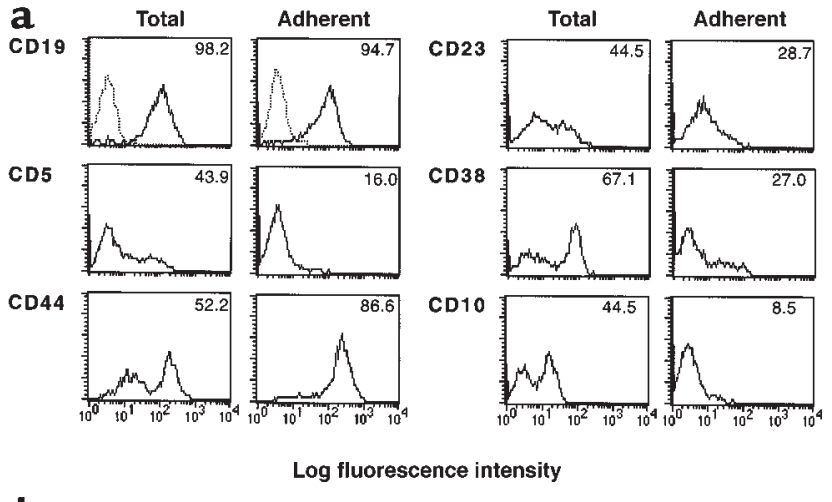

b

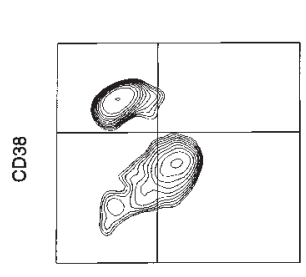

Total

$\lg \mathrm{D}$

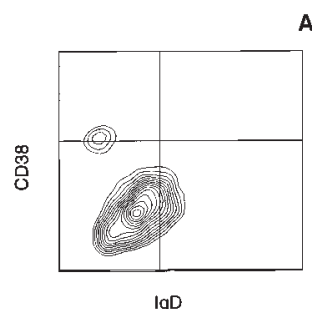

$\lg \mathrm{D}$

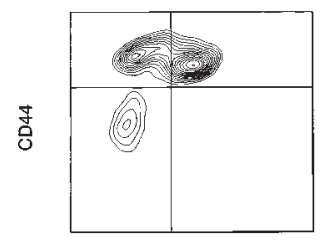

$\lg \mathrm{D}$

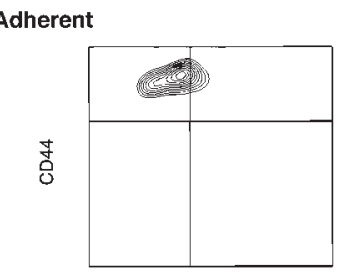

$\lg D$

Figure 4

The E-selectin-binding subpopulation consists of $\mathrm{CD} 19^{+}, \mathrm{CD}^{-}, \mathrm{CD}^{4} 4^{++}$, $\mathrm{CD}^{-} 3^{-}, \mathrm{CD}^{-} 8^{-}, \mathrm{CD}_{10}^{-}$, and IgD- memory B lymphocytes. B cells purified from human tonsils were allowed to attach to $\mathrm{CHO}-\mathrm{E}$ monolayers in $\mathrm{C} 6$ wells under rotation conditions ( $72 \mathrm{rpm}$ ) at $37^{\circ} \mathrm{C}$; then wells were washed, and adherent cells were collected and analyzed by FACS as described in Methods. (a) Histograms showing expression of CD19, CD5, CD44, CD23, CD38, and CD10 on the total and adherent B-cell populations. The percentage of positive cells (highly positive for CD44, ++ ) is shown in the upper right corner of each histogram box. (b) Double staining of total and adherent subpopulations was carried out. Staining with $\mathrm{mAb}$ directed to CD38, CD44 in FL-2, and IgD in FL-1 is shown.

revealed that $23 \%$ of the $\mathrm{B}$ cells were rolling on the surface of the monolayer and that the remaining cells had arrested after the rolling period (Figure 1a). The number of rolling B cells was highest at a shear rate of $1 \mathrm{dyn} / \mathrm{cm}^{2}$ and decreased when the shear was increased to $1.5 \mathrm{dyn} / \mathrm{cm}^{2}$ or higher (Figure $1 \mathrm{~b}$ ). The B-cell rolling velocities were $40 \pm$ 11 at $1.8 \mathrm{dyn} / \mathrm{cm}^{2}$ and decreased to $10 \pm 4$ as the shear stress level was lowered to $1 \mathrm{dyn} / \mathrm{cm}^{2}$ (Figure 1c). Based on these data, the flow rate of $1 \mathrm{dyn} / \mathrm{cm}^{2}$ was used for all subsequent flow adhesion experiments.

To identify the molecules on the endothelial surface involved in these adhesive interactions, endothelial cells were treated with blocking $\mathrm{mAb}$ 's directed to different adhesion molecules. An anti-E-selectin blocking $\mathrm{mAb}$ virtually abrogated these interactions, showing that Eselectin is mediating initial attachment and rolling of $B$ cells on the endothelial monolayer. Neither P-selectin nor vascular cell adhesion molecule-1 (VCAM-1) was

implicated, as blocking mAb's against these molecules did not affect the rolling (Figure 2).

To further study B-cell rolling on endothelial selectins, flow adhesion experiments were performed using monolayers of $\mathrm{CHO}$ cells stably transfected with human Pselectin and E-selectin. B lymphocytes did not attach or roll on parental untransfected $\mathrm{CHO}$ cells (CHO-DUKX) (Figure 3). P-selectin transfectants (CHO-P) were also unable to support B-cell rolling (Figure 3), although they consistently supported rolling of neutrophils and HL60 in experiments performed in parallel (not shown). In contrast, B cells readily interacted with E-selectin transfectants (CHO-E) and rolled at low velocities of $17 \pm 3$ $\mu \mathrm{m} / \mathrm{s}$. The specificity of these adhesive interactions was further demonstrated by treatment of CHO-E monolayers with a blocking $\mathrm{mAb}$ against E-selectin, which completely inhibited rolling of B cells (Figure 3). Rolling interactions were abolished using the $\mathrm{Ca}^{2+}$ chelator EDTA (data not shown).

The subset of tonsillar $B$ lymphocytes interacting with Eselectin bears the memory phenotype. To characterize phenotypically the subset of B cells that roll on E-selectin, we performed adhesion assays to the CHO-E monolayer under rotation conditions, which resembles the flow shear, enabling us to recover and study E-selectin-adherent cells. The expression of different B-cell markers on adherent cells, as well as in the unfractionated population of B cells, was analyzed. Staining with the pan-B-cell marker CD19 showed that both the total and adherent populations comprised only B lymphocytes with no contamination of $\mathrm{CHO}$ cells. The analysis of CD38, CD44, and CD10 expression reveals that unfractionated cells consist of a heterogeneous population that express different levels of these surface markers (Figure 4a). In contrast, the majority of the cells in the adherent population was negative for the GC markers CD38 and CD10, have low levels of the activation markers CD5 and CD23, and have high levels of CD44 (Figure 4a). Thus, Eselectin-adherent $\mathrm{B}$ cells bear the CD38- ${ }^{-} \mathrm{CD}_{44^{++}}, \mathrm{CD}^{-} 0^{-}$ phenotype, described for B cells populating compartments other than the GC.

Resident B cells outside the GC of secondary lymphoid organs comprise naive and memory lymphocytes, which can be distinguished by the expression of cell surface $\operatorname{IgD}$ (1). We therefore decided to investigate the expression of IgD in the total and E-selectin-adherent subpopulation. Double-staining analysis showed that adherent CD38cells were mainly IgD $^{-}$(Figure $4 \mathrm{~b}$ ), thus displaying a phenotype coincident to that observed for secondary lymph node memory B cells. As already described here, the subset of $\mathrm{CD} 8^{+} \mathrm{IgD}^{-}$that corresponded to $\mathrm{GC}$ cells was absent in the adherent population (Figure 4b). In addition, non-GC CD $44^{++}$cells in the unfractionated population consisted of 2 discrete cell populations, $\operatorname{IgD}^{+}$and $\mathrm{IgD}^{-}$, whereas $\mathrm{CD}_{4} 4^{++}$cells in the adherent population were uniformly $\mathrm{IgD}^{-}$memory B cells (Figure 4b). Hence, cells capable of interacting with E-selectin were mainly memory CD38-, CD44+ ${ }^{++}$IgD $^{-}$B lymphocytes.

Further analyses of the expression of different adhesion molecules on E-selectin-adherent cells was performed. The level of LFA-1 integrin was similar in both the total and the adherent subpopulations. In contrast, 
a

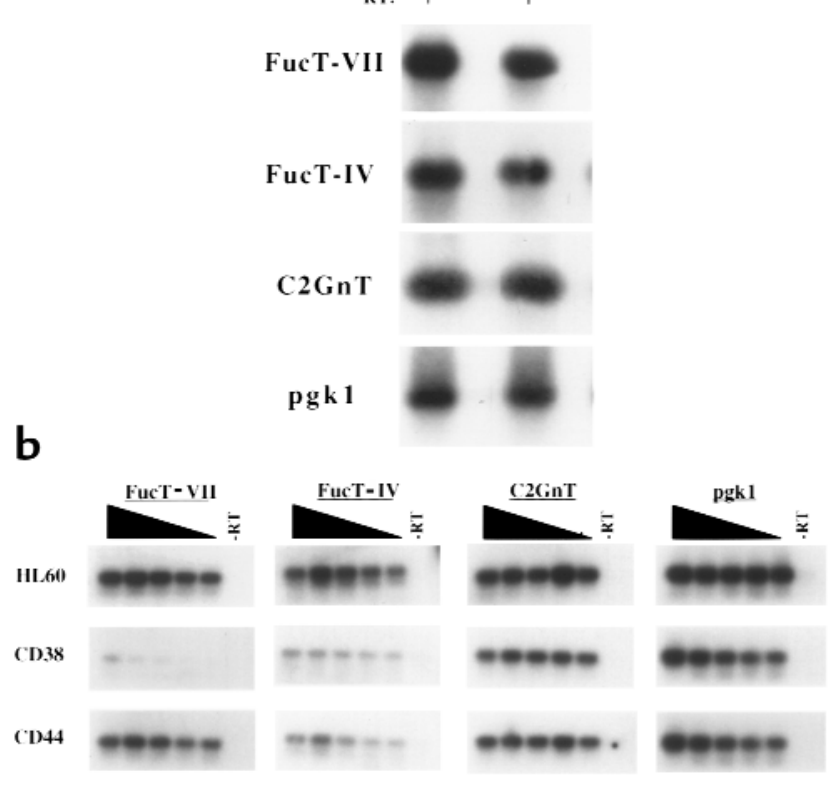

Figure 5

Expression of glycosyltransferase mRNA in human tonsillar B lymphocytes. Expression of FucT-VII, FucT-IV, and C2GnT in purified tonsillar B cells was carried out as described in Methods. pgk1 is a housekeeping enzyme included as an internal control. HL60, a human myeloid cell line, was included as a positive control. (a) The presence or absence of RT in the reaction is indicated by a "+" or "-", respectively. C corresponds to control HL60 cells, and B corresponds to B-cell samples from the total population. (b) B lymphocytes were fractionated into CD $38^{+}$and CD $44^{+}$ cells and were analyzed by semiquantitative RT-PCR, using 2-fold serial dilutions going from left to right. The last lane in each set is the negative control of no RT (-RT).

adherent cells expressed higher levels of the integrin subunits $\alpha 4, \alpha 5, \beta 1, \alpha x$, as well as other adhesion molecules such as L-selectin (Table 1).

$B$-cell rolling on E-selectin is independent of previously described selectin ligands but requires sialic acid on the lymphocyte surface. Different carbohydrate determinants have been shown to decorate the selectin ligands; thus, expression of functional selectin ligands requires glycosylation that is carried out by different $\alpha(1,3)$-fucosyltransferases (FucTs) (4). We therefore investigated the expression of FucTs, as well as carbohydrate determinants, in B lymphocytes. We analyzed the presence of different $(\alpha 1,3)$ FucTs involved in the glycosylation of the E-selectin ligands. The expression of mRNA transcripts for FucT-VII, FucT-IV, and C2GnT was measured by semiquantitative RT-PCR in total RNA isolated from B-cell samples and compared with data obtained using HL60 cells as a positive control. B cells were found to endogenously express FucT-VII, FucT-IV, and C2GnT (Figure 5a). To determine whether these enzymes were selectively expressed in the adherent population, B cells were fractionated into $\mathrm{CD} 44^{+}$and $\mathrm{CD} 38^{+}$cells, and the subpopulations were again analyzed by semiquantitative RT-PCR using 2-fold serial dilutions of input cDNA to assess more accurately the relative differences in mRNA expression. As shown in Figure $5 \mathrm{~b}$, the adherent population $\left(\mathrm{CD} 44^{+}\right)$of B cells expressed at least 32-fold more FucT-VII mRNA than GC $\left(\mathrm{CD} 38^{+}\right)$nonadherent cells, whereas FucT-IV and C2GnT levels were represented at easily detectable levels in both B-cell subpopulations. These results strongly suggest the involvement of FucT-VII in the glycosylation of the Eselectin ligand on $\mathrm{B}$ cells.

Previous flow cytometry studies showed that tonsillar B lymphocytes failed to express CLA, sLe ${ }^{x}, L^{x}$, or $\mathrm{Le}^{\mathrm{a}}$. B cells also lack expression of CD57, CDw65 CD35, CD66, and sulfatides (29). We have extended this analysis by determining the expression of other additional carbohydrate determinants on tonsillar B cells. The epitope recognized by $\mathrm{mAb} 2 \mathrm{H} 5$, but not SNH3 and FH6, was detected in these cells (Figure 6). The mAb's HECA452, CSLEX, and $2 \mathrm{~F} 3$ recognize $s L e^{x}$ or variants of this structure that are FucT-VII-dependent epitopes $(6,37,39,45)$ and have been suggested to bind directly to E-selectin. These epitopes were not found to be expressed in resting B lymphocytes (Figure 6). High-affinity E-selectin ligands, such as PSGL-1, ESL-1, or L-selectin, have been described (16-28). The expression of PSGL-1 was analyzed using 2 specific mAb's, PSL 275 and KPL-1, the latter specifically recognizing the sulfated $\mathrm{NH}_{2}$-terminal domain of this molecule (21). Neither anti-PSGL-1 mAb recognized B lymphocytes (Figure 6). L-selectin was weakly expressed, although the level of expression was higher in the adherent population (Table 1).

Rolling of B cells on CHO-E monolayers was not affected by treatment with adhesion-blocking antibodies against PSGL-1 or L-selectin (Figure 7). The effect of blocking polyclonal anti-ESL-1 antibody was also explored using affinity-purified polyclonal antibodies. Neither of these antibodies had an inhibitory effect on B-cell rolling (Figure 7), thus indicating that interaction of $B$ cells with E-selectin is not mediated by any of the previously described high-affinity E-selectin ligands.

To investigate the biochemical characteristics of the Eselectin ligand(s) expressed by tonsillar B cells, treatment with different enzymes affecting sialylation or glycosylation of the cell surface molecules was carried out. Neuraminidase treatment completely blocked rolling on CHO-E, showing an absolute dependence on sialic acid for this interaction (Figure 8). OSGE, a protease that acts specifically on $O$-sialomucin-like proteins, did not affect B-cell rolling (Figure 8), whereas it completely blocked rolling of HL60 on CHO-P (data not shown). These results suggest that sialic acid-bearing glycans are responsible for the interaction of B lymphocytes with E-selectin.

E-selectin/IgG specifically binds a single 240-kDa glycoprotein from $B$ lymphocytes. Soluble recombinant selectin/IgG fusion proteins have been used to identify high-affinity selectin ligands such as PSGL-1 or ESL-1 by affinity precipitation assays $(16,17,26,27)$. To characterize the ligand for E-selectin on B lymphocytes, surface biotinylated lysates obtained from the total population of tonsillar B cells were precipitated with the antibody-like fusion protein E-selectin/IgG. This chimeric protein, but not human $\mathrm{IgG}$, precipitated a band of approximately $240 \mathrm{kDa}$ under reducing conditions (Figure 9a). Antibodies against ESL1 precipitated a band of $150 \mathrm{kDa}$ that was not precipitated by the E-selectin chimera, thus indicating that ESL-1 is 

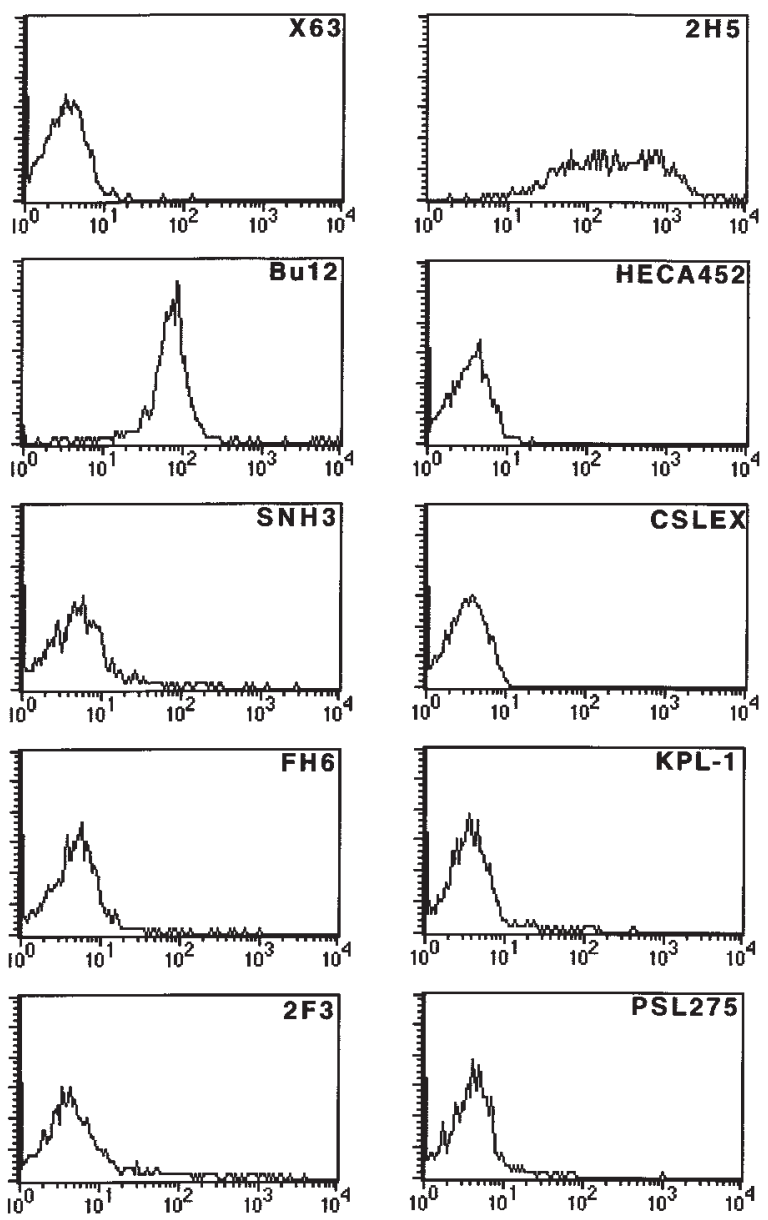

Log fluorescence intensity

\section{Figure 6}

Surface expression of carbohydrate determinants on B lymphocytes. Total B-cell samples readily purified from tonsils were analyzed by FACS as described in Methods. Histograms representing cell surface expression of CD19 (Bu12), different carbohydrate epitopes (SNH3, FH6, 2F3, 2H5, HECA452, and CSLEX), PSGL-1 (KPL-1 and PSL 275), as well as nonbinding control antibody (X63) are shown.

present on the surface of B cells but is unable to bind Eselectin. Immunoprecipitation using polyclonal antibodies against PSGL-1 confirmed its absence from the B-cell surface. As a control for the selective surface labeling with biotin, an antibody against Hsp90 was unable to precipitate this intracellular protein from the surface-labeled lysates (Figure 9a), whereas it did recognize Hsp 90 from metabolically intracellular labeled 32dcl3 cells (Figure 9b). Thus, ESL-1 and E-selectin-binding protein of $240 \mathrm{kDa}$ were present on the surface of B cells. The $240-\mathrm{kDa}$ band was completely removed from the E-selectin/IgG matrix by washing the beads in the presence of $3 \mathrm{mM}$ EDTA (Figure 10a). In addition, the fusion protein VE-cadherin/IgG was unable to precipitate the $240-\mathrm{kDa}$ band (Figure $10 \mathrm{~b}$ ). The $\mathrm{Ca}^{2+}$-dependent binding of the $240-\mathrm{kDa}$ protein to Eselectin and the failure to bind human IgG or VE-cadherin/IgG suggest that the selectin part in the Eselectin/IgG fusion protein is responsible for binding to the $240-\mathrm{kDa}$ protein. Furthermore, preincubation of the fusion protein with the cell adhesion-blocking antibody
UZ4 against mouse E-selectin, but not with a control antibody, partially inhibited the precipitation of the $240-\mathrm{kDa}$ ligand (Figure 10d). Similar levels of inhibition were observed for the precipitation of ESL-1 from 32Dcl3 cells, using the same E-selectin fusion protein (34).

To confirm the requirement of sialic acid for the binding of the $240-\mathrm{kDa}$ ligand to the E-selectin, B lymphocytes were treated with or without neuraminidase and precipitated with the E-selectin/IgG or an antibody against ESL-1 (Figure 10c). Removal of sialic acid impaired the interaction of the $240-\mathrm{kDa}$ ligand to Eselectin. In contrast, the sialidase treatment did not block the precipitation of ESL-1, which only suffered a slight decrease in the apparent molecular weight, thus showing that the disappearance of the $240-\mathrm{kDa}$ band was due to lack of interaction with the E-selectin/IgG and not to unspecific degradation.

To determine the involvement of $\mathrm{N}$-linked glycans in the binding of the $240-\mathrm{kDa}$ glycoprotein ligand to Eselectin/IgG, we treated the biotin-labeled ligand that had been eluted with EDTA from the E-selectin/IgG affinity matrix with endoglycosidase F. This treatment caused a slight but clearly detectable decrease in the apparent molecular weight of the glycoprotein ligand (Figure 10e, lane 2), showing that this molecule carries $\mathrm{N}$-linked carbohydrate side chains. Aliquots of both the endoglycosidase F and the mock-treated samples were reprecipitated with E-selectin/IgG, thus indicating that the binding of the $240-\mathrm{kDa}$ ligand to E-selectin does not require $\mathrm{N}$-linked glycans.

\section{Discussion}

Purified human tonsillar B cells are composed of different subpopulations, each displaying a well-defined phenotype (1). Our results show that a subset of B lymphocytes purified from human tonsils interact with Eselectin, but not P-selectin, under flow conditions and that this interaction was independent of known Eselectin binding proteins. The cells that bound Eselectin were studied further by performing adhesion assays under rotation conditions to recover adherent B cells. The adherent cells expressed low levels of the GC markers CD10 and CD38, whereas they expressed high levels of CD44. Thus, GC cells were unable to interact with E-selectin. Accordingly, other studies have shown that GC B cells lack expression of the homing receptor L-selectin and are unresponsive to stromal cell-derived factor- $1 \alpha$ (SDF-1 $\alpha)$ and TNF- $\alpha$ (46-48). Altogether, these results suggest a nonmigratory phenotype of GC cells most likely related to their differentiation state. This is consistent with previous studies showing that these cells were unable to recirculate through lymphoid organs (49). Non-GC B cells (CD38-, CD44+') include cells of the naive and memory phenotypes that can be identified by the expression of surface IgD (1). The subset of cells that we found to be capable of interacting with E-selectin bears the memory phenotype $\left(\mathrm{CD} 44^{++}\right.$, $\left.\mathrm{CD}^{-} 8^{-}, \mathrm{IgD}^{-}\right)$. On the basis of our observations, we can assign a novel adhesive function for memory B cells, rolling on E-selectin, that might be important for directing the migration of these cells.

We have reported previously that phorbol-activated, but 

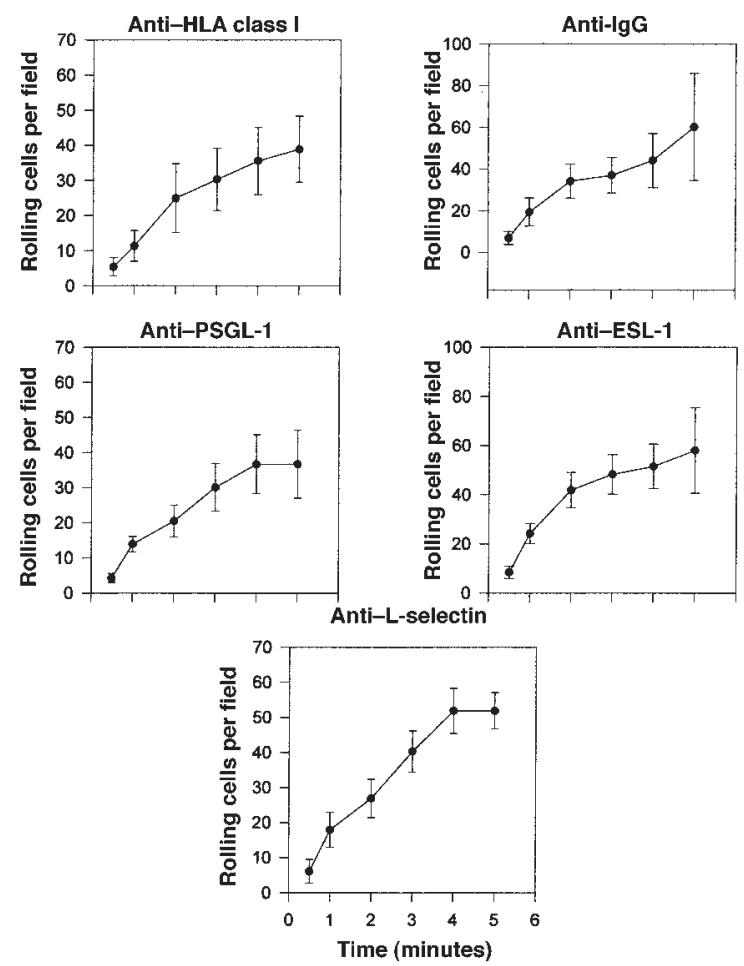

Figure 7

ESL-1, PSGL-1, and L-selectin do not mediate rolling of B cells on CHOE. B cells were treated for 20 minutes at $4^{\circ} \mathrm{C}$ with $10 \mu \mathrm{g} / \mathrm{mL}$ of controls anti-HLA class I (W6/32) and anti-lgG, or with blocking anti-PSGL-1 (KPL1), L-selectin (LAM 1/3), or polyclonal anti-ESL-1 (89060). Cells were then perfused across CHO-E monolayers at $1 \mathrm{dyn} / \mathrm{cm}^{2}$, and the number of rolling cells was calculated. The arithmetic mean \pm SEM number of rolling cells calculated from 3 independent experiments is shown.

not resting, tonsillar $\mathrm{B}$ lymphocytes interact with $\mathrm{E}$ - and $\mathrm{P}$ selectins under static conditions (29). The apparent differences in the results obtained in the previous study compared with the current work are most likely due to the adhesion conditions used in each study. Adhesion through all 3 selectins has been shown to require a minimum level of fluid shear stress to support rolling interactions $(50,51)$. Thus, studies under flow are the most appropriate technique to study selectin interactions in vitro $(3,4)$. On the other hand, the use of flow assays for studying adhesion of tonsillar B lymphocytes, which are not subjected to flow in their physiologic localization, might seem contradictory. However, the subpopulation of memory and plasma B cells generated in the tonsils will return to the circulation and will interact with the endothelium under flow conditions (2). Thus, it seems reasonable to investigate the migratory capacities of these cells under flow in order to learn about their functional behavior.

It is of interest to note the differences in the ability of resident and PB B cells to interact with endothelial selectins. Although we have found that memory tonsillar B cells can interact with E-selectin but not P-selectin, others have reported that PB B cells interact with P-selectin, and only weakly with E-selectin, under flow conditions (30). The differences regarding P-selectin binding can be simply explained by the fact that PSGL-1 is expressed by circulating blood B cells but not tonsillar B cells (refs. 21, 30; Fig- ures 6 and 9). These results suggest that PSGL-1 expression is downregulated from the B-cell surface upon entering the tonsils during the recirculation process. Presumably, the small number of circulating blood B cells capable of binding to E-selectin may correspond to the percentage of memory cells present in the PB pool that were originated in the secondary lymphoid organs, although formal demonstration of this notion needs further investigation.

The expression of different carbohydrate epitopes has been studied in the present and previous works (29). We have found no expression of the CLA epitope recognized by HECA452, which mediates skin homing of memory $\mathrm{T}$ cells by interacting with E-selectin (6) and has been shown to decorate PSGL-1 (52). Although B cells express the epitope recognized by $\mathrm{mAb} 2 \mathrm{H} 5$, this carbohydrate epitope does not seem to be involved in binding to Eselectin because it is broadly expressed in the total population of $\mathrm{B}$ cells, whereas only a subpopulation binds to E-selectin. This is in agreement with previous works showing that $2 \mathrm{H} 5$ binds structures other than $\mathrm{sLe}^{\mathrm{x}}$ or other related sialylated or fucosylated structures (45). In addition, although this $\mathrm{mAb}$ has been shown to block adhesion of HL60 to P- and E-selectin (53), it was unable to block B-cell rolling on CHO-E. Furthermore, $2 \mathrm{H} 5$ precipitated an 80- to 90-kDa band under reducing conditions on the B-cell lysates (not shown) that does not correspond to any of the protein ligands precipitated with the E-selectin/IgG chimera.

E-selectin has been shown to interact with PSGL-1, ESL-1, and L-selectin in certain cell types. However, none of these ligands seem to mediate interaction of tonsillar memory B cells with E-selectin, because specific blocking antibodies do not affect B-cell rolling. The antibodies used for blocking the L-selectin molecule are directed to the lectin domain protein region and not to the carbohydrates decorating this molecule.
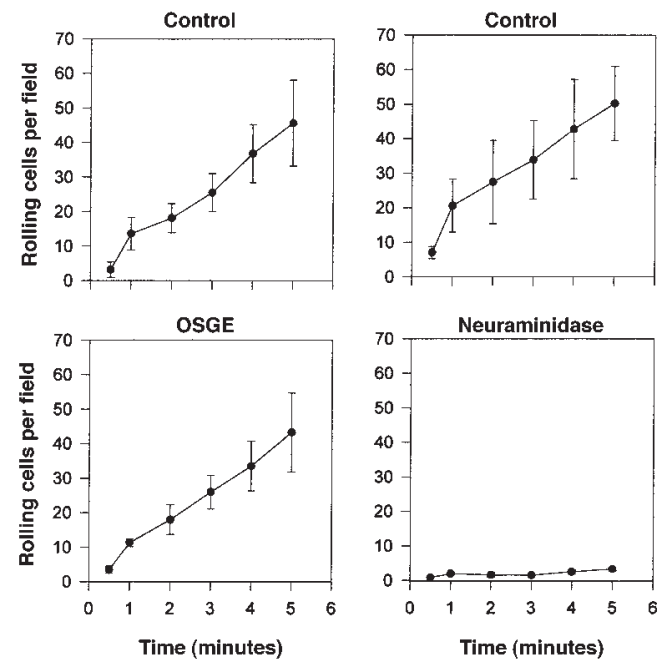

\section{Figure 8}

Neuraminidase treatment of $\mathrm{B}$ cells greatly reduces rolling on $\mathrm{CHO}-\mathrm{E}$ monolayers. B cells were treated for 1 hour at $37^{\circ} \mathrm{C}$ with or without 40 $\mu \mathrm{g} / \mathrm{mL}$ OSGE or $0.1 \mathrm{U} / \mathrm{mL}$ neuraminidase, and were then washed and perfused across CHO-E monolayers. The number of rolling cells was determined as described previously. Values represent arithmetic mean \pm SEM number of rolling cells calculated from 3 independent experiments. 

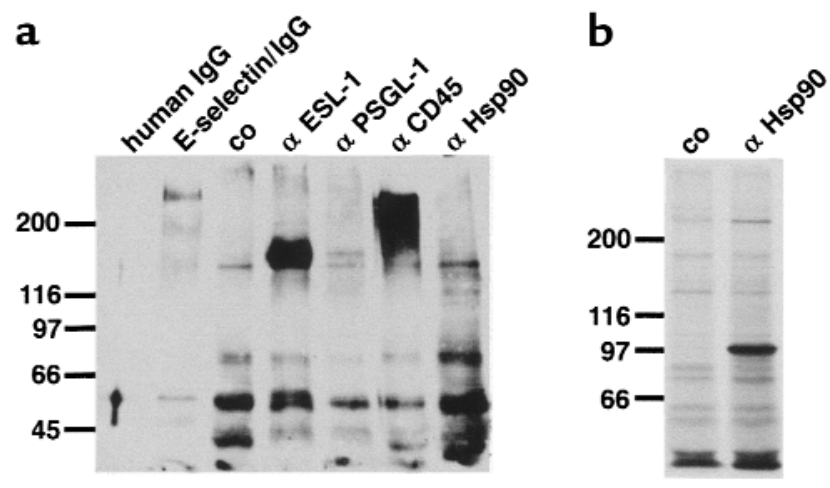

\section{Figure 9}

Affinity isolation of E-selectin ligands from human tonsillar B cells. B cells were isolated from human tonsils and surface biotinylated, as described in Methods (a). The 32Dcl3 cells were metabolically labeled with $\left[{ }^{35} \mathrm{~S}\right]$ methionine/ $\left[{ }^{35} \mathrm{~S}\right]$ cysteine as described in Methods (b). Detergent extracts of the cells were immunoprecipitated with human IgG as control (human IgG), E-selectin/lgG (E-selectin/lgG), rabbit control IgG (co), affinity-purified rabbit antibodies against ESL-1 ( $\alpha$ ESL-1) or PSGL-1 ( $\alpha$ PSGL1 ), an mAb against CD45 ( $\alpha$ CD45) or Hsp90 ( $\alpha$ HSP90), or a control mAb (co). Immunoprecipitated antigens were isolated by SDS-PAGE under reducing conditions, transferred to nitrocellulose, and detected with peroxidase-conjugated streptavidin and ECL (a). In b, electrophoresed antigens were viewed by fluorography. Molecular mass markers (in kilodaltons) are indicated on the left.

Thus, our results indicate that the lectin domain is not involved in the rolling of B cells on E-selectin. However, it has been reported previously that L-selectin from lymphocytes is unable to bind E-selectin, in contrast to neutrophil L-selectin (54). The inability of L-selectin from B cells to interact with E-selectin was further confirmed in affinity precipitation assays using a recombinant form of E-selectin, which showed that PSGL-1, L-selectin, and ESL-1 were not precipitated by the Eselectin chimera. Instead, we have found that the Eselectin/IgG fusion protein precipitates a band of approximately $240 \mathrm{kDa}$ from the surface of tonsillar B cells. The precipitation of the $240-\mathrm{kDa}$ band was shown to be E-selectin-specific by several criteria. First, no binding of the protein occurs to human IgG or VE-cadherin/IgG fusion protein. Second, the binding is $\mathrm{Ca}^{2+}$ dependent. Third, the binding is partially inhibited by the anti-mouse E-selectin mAb, but not by an antihuman IgG (Fc part)-specific mAb. Fourth, the binding is drastically reduced if sialic acid is removed from the B-cell surface by treatment with neuraminidase. Whether the latter molecule is related to the $250-\mathrm{kDa}$ ligand of E-selectin found in bovine $\gamma / \delta$ T cells $(24,28)$ is not known. It is intriguing that the E-selectin ligands expressed by tonsillar B cells appear to be sensitive to neuraminidase but not to $O$-glycoprotease treatment, as has also been reported for the $\gamma / \delta \mathrm{T}$-cell ligand (55). Furthermore, other putative E-selectin ligands found in human $\mathrm{T}$ lymphocytes share similar molecular weights with those found in B cells (24). Whether Eselectin ligands expressed by $B$ cells are the same molecules as those detected on $\mathrm{T}$ lymphocytes is a matter that deserves further investigation.

It is surprising that ESL-1, expressed at high levels on the surface of tonsillar B cells, is unable to interact with E-selectin, despite the fact that these cells express mRNA of FucT-IV and FucT-VII. The expression of these FucTs in CHO cells is sufficient to convert ESL1 into an E-selectin-binding glycoform (56). Similarly, it is surprising that the analyzed tonsillar B cells do not express the sLe ${ }^{x}$-like epitope HECA452, which is normally expressed on human cells that express these FucTs. This could argue for differences in the glycosylation machinery of B cells. In this respect, it is interesting to note that human lymphocytes, in contrast to human neutrophils (25), are unable to express an E-selectin-binding glycoform of L-selectin (54), although they can express E- and P-selectin-binding glycoforms of PSGL-1, which require the expression of FucT-VII. Nevertheless, the selective expression of FucT-VII by CD $44^{+}$E-selectin-adherent B cells is in accordance with the rolling of tonsillar memory B cells on E-selectin and with data suggesting that FucT-VII is responsible for the generation of functional ligands in vitro $(45,56,57)$ and in vivo $(58)$. The presence of $\mathrm{C} 2 \mathrm{GnT}$, an enzyme involved in the generation of functional PSGL-1 (4), might be related to the presence of functional PSGL-1 in PB B cells, which are the cells that populate the tonsils and lose the expression of PSGL-1. Our results suggest that the downregulated expression of PSGL-1 from the surface membrane of $B$ cells after they enter the tonsils is uncoupled to the expression of the enzymes involved in the functional modification of this molecule.

The homing of $\mathrm{T}$ cells to different effector sites has been well studied, although the mechanisms by which memory $\mathrm{T}$ cells are formed is less known. By contrast, differentiation of B cells leading to the formation of memory and plasma cells has been extensively studied, although much less effort has been directed toward understanding the pathways of recirculation and homing of B cells as well as the molecules implicated in these processes. It is well known that memory B cells from secondary lymphoid organs home to secretory sites $(2,59)$. There is an increasing body of evidence supporting the homing of tonsillar B cells to secretory sites, such as nasal and bronchial mucosa as well as salivary and lacrimal glands (60-62), but the mechanisms regulating these trafficking pathways are largely unknown. Moreover, the constitutive expression of E-selectin in HEV of normal tonsils, adenoids $(9,10)$, and skin $(6,12,13)$ has been reported, suggesting that E-selectin might be implicated in the recirculation of $\mathrm{B}$ cells through the peripheral secondary lymphoid organs and the mucosae. On the basis of the observations reported herein, we postulate that E-selectin plays a key role in the homing of memory B cells to secretory mucosae and in their recirculation through the tonsils and other local secondary lymphoid organs. This issue is supported by the fact that mice deficient in both E- and P-selectins show an increased susceptibility to mucocutaneous infections (63-65). On the other hand, B cells have also been found forming clusters of tightly packed cells at restricted sites in the inflamed tissue (66). However, the phenotypic characterization of $\mathrm{B}$ cells found in inflamed tissues has not been reported. Given that E-selectin is mainly an endothelial adhesion mole- 


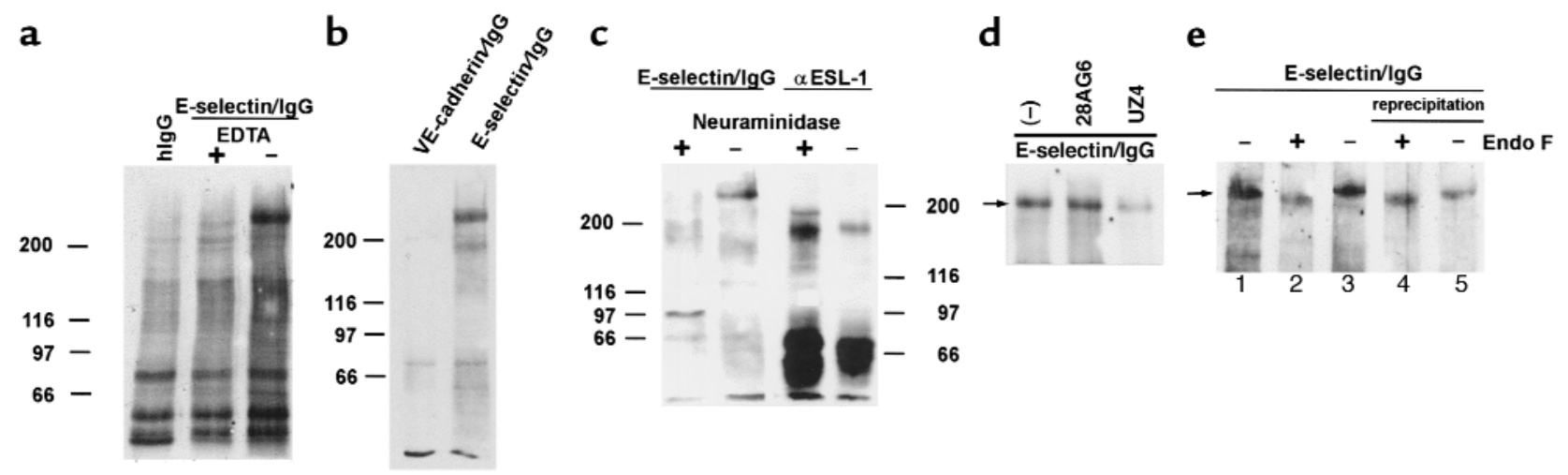

\section{Figure 10}

The binding of the $240-\mathrm{kDa}$ ligand to the E-selectin/lgG fusion protein is E-selectin-specific. This binding requires sialic acid but is independent of $\mathrm{N}$ linked carbohydrate side chains. B lymphocytes were surface biotinylated, and detergent extracts were immunoprecipitated with human IgG as control (hlgG), E-selectin/lgG, VE-cadherin/lgG, or affinity-purified rabbit anti-ESL-1 ( $\alpha E S L-1)$. (a) E-selectin/lgG matrix was washed in the presence or absence of $3 \mathrm{mM}$ EDTA. (c) B lymphocytes were treated with or without $1 \mathrm{U}$ of neuraminidase before surface biotinylation. (d) Before incubation with the Eselectin/IgG affinity matrix with the cell extracts, the matrices were incubated with PBS (-), $400 \mu \mathrm{g}$ of the control mAb $28 \mathrm{AG}$ against human IgG $\mathrm{Fc}$ part, or $400 \mu \mathrm{g}$ of the mAb UZ4 against mouse E-selectin. (e) The 240-kDa ligand was affinity isolated with E-selectin/lgG and eluted with EDTA. The eluted material was either directly electrophoresed (lane 1) or treated with (lanes 2 and 4) or without (lanes 3 and 5 ) $0.5 \mathrm{U}$ of endoglycosidase $\mathrm{F}$ for 12 hours at $37^{\circ} \mathrm{C}$. A third of the treated samples was directly electrophoresed (lanes 2 and 3) or reprecipitated with E-selectin/lgG (lanes 4 and 5).Labeled proteins were electrophoresed on an $6 \%$ polyacrylamide gel under reducing conditions, transferred to nitrocellulose, and detected with peroxidase-conjugated streptavidin. Molecular mass markers (in kilodaltons) are indicated. In $\mathbf{d}$ and $\mathbf{e}$, the arrows indicate the 240-kDa E-selectin ligand.

cule found in inflamed tissues, it could be involved in the extravasation of B cells through the endothelial barrier at sites of inflammation. Our data provide insights for elucidating what molecules are implicated in the homing of resident memory $\mathrm{B}$ cells to tertiary sites.

\section{Acknowledgments}

We are indebted to R.T. Camphausen for the generous gift of CHO-DUKX, CHO-P, and CHO-E that made this work possible. We also acknowledge the kind gift of mAb's by R. Hallmann, J.M. Harlan, G.D. Johnson, E.C. Butcher, P.I. Teraski, R. Kannagi, R.T. Camphausen, and T.F. Tedder. We want to thank M.A. del Pozo, M. Vicente, M.D. Gutierrez, A. Batista, and M. Viton for insightful advice and excellent technical support. We acknowledge Servicio de Otorrinolaringologia del Hospital Niño Jesus (Madrid, Spain) and Rudack Klinik und Poliklinik für Hals-Nasen und Ohrenheilkunde Muenster (Muenster, Germany) for generous provision of human tonsils. This work was supported by grants PM950162 from the Ministerio de Educación y Ciencia (to M.O. de Landázuri), grant FPI from the Comunidad Autonoma de Madrid (to M.C. Montoya), grant SFB293 from the Deutsche Forschungsgemeinschaft, Germany (to D. Vestweber), grant CB204/RPG-96-097-03 from the American Cancer Society (to G. Kansas), and grants HL-53993 and HL-36028 from the National Institutes of Health (to F.W. Luscinskas). G. Kansas is an Established Investigator of the American Heart Association.

1. Liu, Y-J., and Arpin, C. 1997. Germinal center development. Immunol. Rev. 156:111-126.

2. Sprent, J. 1997. Immunological memory. Curr. Opin. Immunol. 9:371-379.

3. Salmi, M., and Jalkanen, S. 1997. How do lymphocytes know where to go: current concepts and enigmas of lymphocyte homing. Adv. Immunol. 64:139-218.

4. Kansas, G. 1996. Selectins and their ligands: current concepts and controversies. Blood. 88:3259-3287.

5. Olofsson, A.M., et al. 1994. E-selectin mediates leukocyte rolling in interleukin-1 treated mesentery venules. Blood. 84:2749-2758.

6. Picker, L.J., Kishimoto, T.K., Smith, C.W., Warnock, R.A., and Butcher, E.C. 1991. ELAM-1 is an adhesion molecule for skin homing T cells. Nature. 349:796-799.

7. Nguyen, M., Strubel, N., and Bischoff, J. 1993. A role for sialyl Lewis -X/A glycoconjugates in capillary morphogenesis. Nature. 365:267-269.
8. Kralig, B.M., et al. 1996. E-selectin is present in proliferating endothelial cells in human hemangiomas. Am. J. Pathol. 148:1181-1191.

9. Andoh, N., et al. 1996. Expression of E- and P-selectins by vascular endothelial cells in human tonsils. Acta Otolaryngol. (Stockb) Suppl. 523:52-54.

10. Perry, M.E., Niall, W., Kirkpatrik, A., Happerfield, L.C., and Gleeson, M.J. 1996. Expression of adhesion molecules on the microvasculature of the pharyngeal tonsil (adenoid). Acta Oto-Laryngol. Suppl. 523:47-51.

11. Schweitzer, K.M., et al. 1996. Constitutive expression of E-selectin and vascular cell adhesion molecule-1 on endothelial cells of hematopoietic tissues. Am. J. Pathol. 148:165-175.

12. Norton, J., Sloane, J.P., Al-Saffar, N., and Haskard, D.O. 1991. Vessel associated adhesion molecules in normal skin and acute graft-versus-host disease. J. Clin. Pathol. 44:586-591.

13. Uccini, S., et al. 1993. Molecular mechanisms involved in intraepithelial lymphocyte migration: a comparative study in skin and tonsil. J. Pathol. 169:413-419.

14. Hurwitz, A.A., Lyman, W.D., Guida, M.P., Calderon, T.M., and Berman, J.W. 1992. Tumor necrosis factor $\alpha$ induces adhesion molecule expression on human fetal astrocytes J. Exp. Med. 176:1631-1636.

15. Essani, N.A., McGuire, G.M., Manning, A.M., and Jaesche, H. 1996. Endotoxin-induced activation of the nuclear transcription factor $\mathrm{kB}$ and expression of E-selectin messenger RNA in hepatocytes, Kupffer cells and endothelial cells in vivo. J. Immunol. 156:2956-2963.

16. Moore, K.L., et al. 1992. Identification of a specific glycoprotein ligand for P-selectin (CD62) on myeloid cells. J. Cell Biol. 118:445-456.

17. Sako, D., et al. 1993. Expression cloning of a functional glycoprotein ligand for P-selectin. Cell. 75:1179-1186.

18. Asa, D., et al. 1995. The P-selectin glycoprotein ligand functions as a common human leukocyte ligand for P- and E-selectins. J. Biol. Chem. 270:11662-11670.

19. Walcheck, B., Moore, K.L., McEver, R.P., and Kishimoto, T.K. 1996. Neutrophil-neutrophil interactions under hydrodynamic shear stress involve L-selectin and PSGL-1. A mechanism that amplifies initial leukocyte accumulation on P-selectin in vitro. J. Clin. Invest. 98:1081-1087.

20. Tu, L., et al. 1996. L-selectin binds to P-selectin glycoprotein ligand-1 on leukocytes. Interactions between the lectin, epidermal growth factor and consensus repeat domains of the selectins determine ligand binding specificity. J. Immunol. 157:3995-4004.

21. Snapp, K.R., et al. 1998. A novel P-selectin glycoprotein ligand-1 monoclonal antibody recognizes an epitope within the tyrosine sulfate motif of human PSGL-1 and blocks recognition of both P- and L-selectin. Blood. 91:154-164.

22. Snapp, K.R., Wagers, A.J., Craig, R., Stoolman, L.M., and Kansas, G.S. 1996. P-selectin glycoprotein ligand-1 (PSGL-1) is essential for adhesion to P-selectin but not E-selectin in stably transfected hematopoietic cell lines. Blood. 89:896-901.

23. Steegmaier, M., Blanks, J.E., Borges, E., and Vestweber, D. 1997. P-selectin 
glycoprotein ligand-1 mediates rolling of mouse bone marrow-derived mast cells on P-selectin but not efficiently on E-selectin. Eur. J. Immunol. 27:1339-1345.

24. Jones, W.M., Watts, G.M., Robinson, M.K., Vestweber, D., and Jutila, M.A 1997. Comparison of E-selectin-binding glycoprotein ligands on human lymphocytes, neutrophils, and bovine $\gamma \delta$ T cells. J. Immunol. 159:3574-3583.

25. Zollner, et al. 1997. L-selectin from human, but not mouse neutrophils binds directly to E-selectin. J. Cell Biol. 136:707-716.

26. Lenter, M., Levinovitz, A., Isenmann, S., and Vestweber, D. 1994. Monospecific and common glycoprotein ligands for E- and P-selectin on myeloid cells. J. Cell Biol. 125:471-481.

27. Steegmaier, M., et al. 1995. The E-selectin-ligand ESL-1 is a variant of a receptor for fibroblast growth factor. Nature. 373:615-620.

28. Walcheck, B., Watts, G., and Jutila, M.A. 1993. Bovine $\gamma / \delta$ T cells bind Eselectin via a novel glycoprotein receptor: first characterization of a lymphocyte/E-selectin interaction in an animal model. J. Exp. Med. 178:853-863.

29. Postigo, A.A., Marazuela, M., Sanchez-Madrid, F., and de Landázuri, M.O. 1994. B lymphocyte binding to E- and P-selectins is mediated through de novo expression of carbohydrates on in vitro and in vivo activated human B cells. J. Clin. Invest. 94:1585-1596.

30. Yago, T., et al. 1997. Analysis of initial attachment of B cells to endothelial cells under flow conditions. J. Immunol. 158:707-714.

31. Vachino, G., et al. 1995. P-selectin glycoprotein ligand-1 is the major counter-receptor for P-selectin on stimulated T cells and is widely distributed in non-functional form on many lymphocytic cells. J. Biol. Chem. 270:21966-21974.

32. Bevilacqua, M.P., Pober, J.S., Mendrick, D.L., Cotran, R.S., and Gimbrone, M.A., Jr. 1987. Identification of an inducible endothelial-leukocyte adhesion molecule. Proc. Natl. Acad. Sci. USA. 84:9238-9242.

33. Hallmann, A., Zimmerman, U., Sorokin, L.M., Needham, L., and Mark, K.v.d. 1995. Adhesion of leukocytes to the inflamed endothelium. Scand. J. Rheumatol. 24(Suppl. 101):107-109.

34. Levinovitz, A. Mühlhoff, J., Isenman, S., and Vestweber D. 1993. Identification of a glycoprotein ligand for E-selectin on mouse myeloid cells. J. Cell Biol. 121:449-459.

35. Postigo, A.A., Sánchez-Mateos, P., Lazarovits, A.I., Sánchez-Madrid, F., and de Landázuri, M.O. 1993. $\alpha 4 \beta 7$ integrin mediates B cell binding to fibronectin and vascular cell adhesion molecule-1. Expression and function of $\alpha 4$ integrins on human B lymphocytes. J. Immunol. 151:2471-2483

36. Carlos, T., et al. 1990. Vascular cell adhesion molecule-1 (VCAM-1) mediates lymphocyte adhesion to cytokine-activated cultured human endothelial cells. Blood. 76:965-970.

37. Fukushima, K., et al. 1984. Characterization of sialosylated Lewis $\mathrm{x}$ as a new tumor associated antigen. Cancer Res. 44:5279-5285.

38. Sawada, M., et al. 1993. Specific expression of a complex sialyl Lewis X antigen on high endothelial venules of human lymph nodes: possible candidate for L-selectin ligand. Biochem. Biophys. Res. Commun. 193:337-347.

39. Ohmori, K., et al. 1993. A distinct type of sialyl Lewis X antigen defined by a novel monoclonal antibody is selectively expressed on helper memory T cells. Blood. 82:2797-2805.

40. Spertini, O., Kansas, G.S., Reiman, K.A., Mackay, C.R., and Tedder, T.F. 1991. Function and evolutionary conservation of distinct epitopes on the leukocyte adhesion molecule-1 (LAM-1) that regulate leukocyte migration. J. Immunol. 147:942-949.

41. Montoya, M.C., Luscinskas, F.W., del Pozo, M.A., Aragonés, J., and de Landázuri, M.O. 1997. Reduced intracellular oxidative metabolism promotes firm adhesion of human polymorphonuclear leukocytes to vascular endothelium under flow conditions. Eur. J. Immunol. 27:1942-1951.

42. Hahne, M., Jöger, U., Isenmann, S., Hallmann, R., and Vestweber, D. 1993. Five tumor necrosis factor-inducible cell adhesion mechanisms on the surface of mouse endothelioma cells mediate the binding of leukocytes. J. Cell Biol. 121:655-664.

43. Gotsch, U., et al. 1997. VE-cadherin antibody accelerates neutrophil recruitment in vivo. J. Cell Sci. 110:583-588.

44. Borges, E., et al. 1997. The binding of T cell-expressed P-selectin glycoprotein ligand-1 to E- and P-selectin is differentially regulated. J. Biol.
Chem. 272: 28786-28792

45. Wagers, A.J., Stoolman, L.M., Kannagi, R., Craig, R., and Kansas, G.S. 1997. Expression of leukocyte fucosyltransferases regulates binding to E-selectin. Relationship to previously implicated carbohydrate epitopes. J. Immunol. 159:1917-1929.

46. Munro, J.M., Briscoe, D.M., and Tedder, T.F. 1996. Differential regulation of leukocyte L-selectin (CD62L) expression in normal lymphoid and inflamed extralymphoid tissues. J. Clin. Pathol. 49:721-727.

47. Bleul, C.C., Schultze, J.L., and Springer T.A. 1998. B lymphocyte chemotaxis regulated in association with microanatomic localization, differentiation state, and B cell receptor engagement. J. Exp. Med. 187:753-762.

48. Corcione, A., et al. 1997. Recombinant tumor necrosis factor enhances the locomotion of memory and naive lymphocytes from human tonsils through the selective engagement of the type II receptor. Blood. 90:4493-4501.

49. Reichert, R.A., Gallatin, W.M., Weissman, I.L., and Butcher, E.C. 1983. Germinal center B cells lack homing receptors necessary for normal lymphocyte recirculation. J. Exp. Med. 157:813-827.

50. Finger, E.B., et al. 1996. Adhesion through L-selectin requires a threshold of hydrodynamic shear. Nature. 379:266-269.

51. Lawrence, M.B., Kansas, G.S., Kunkel, E.J., and Ley, K. 1997. Threshold levels of fluid shear promote leukocyte adhesion through selectins (CD62L, P, E). J. Cell Biol. 136:717-727.

52. Fuhlbrigge, R.C., Kieffer, J.D., Armerding, D., and Kupper, T.S. 1997. Cutaneous lymphocyte antigen is a specialized form of PSGL-1 expressed on skin-homing T cells. Nature. 389:978-981.

53. Tamatani, T., et al. 1995. Recognition of consensus CHO structure in ligands for selectins by novel antibody against sialyl Lewis X. Am. J. Physiol. 269:H1282-H1287.

54. Picker, L.J., et al. 1991. The neutrophil selectin LECAM-1 presents carbohydrate ligands to the vascular selectins ELAM-1 and GMP-140. Cell. 66:921-933.

55. Jutila, M.A., and Kurk, S. 1996. Analysis of bovine $\gamma \delta$ T cell interactions with E-, P-, and L-selectin. Characterization of lymphocyte on lymphocyte rolling and the effects of $O$-glycoprotease. J. Immunol. 156:289-296.

56. Zollner, O., and Vestweber, D. 1996. The E-selectin ligand-1 is selectively activated in Chinese hamster ovary cells by the $\alpha(1,3)$-fucosyltransferases IV and VII. J. Biol. Chem. 271:33002-33008.

57. Knibbs, R.N., et al. 1998. $\alpha(1,3)$-fucosyltransferase VII-dependent synthesis of P-and E-selectin ligands on cultured $\mathrm{T}$ lymphoblasts. $J$. Immunol. 161:6305-6315.

58. Mály, P., et al. 1996. The $\alpha(1,3)$ fucosyltransferase Fuc-TVII controls leukocyte trafficking through an essential role in L- E-, and P-selectin ligand biosynthesis. Cell. 86:643-653.

59. Brandtzaeg, P. 1996. The B-cell development in tonsillar lymphoid follicles. Acta Oto-Laryngol. Suppl. 523:55-59.

60. Liu, Y.-J., et al. 1995. Memory B cells from human tonsils colonize mucosal epithelium and directly present antigen to $T$ cells by rapid upregulation of B7-1 and B7-2. Immunity. 2:239-248.

61. Brandtzaeg, P. 1995. The role of humoral mucosal immunity in the induction and maintenance of chronic airway infections. Am. J. Respir. Crit. Care Med. 151:2081-2087.

62. Brandtzaeg, P. 1992. Humoral immune response patterns of human mucosae: induction and relation to bacterial respiratory tract infections. J. Infect. Dis. 165(Suppl. 1):S167-S176.

63. Bullard, D.C., et al. 1996. Infectious susceptibility and severe deficiency of leukocyte rolling and recruitment in E-selectin and P-selectin double mutant mice. J. Exp. Med. 183:2329-2336.

64. Frenette, P.S., Mayadas, T.N., Rayburn, H., Hynes, R.O., and Wagner, D. 1996. Susceptibility to infection and altered hematopoiesis in mice deficient in both P- and E-selectins. Cell. 84:563-574.

65. Muñoz, F.M., Hawkins, E.P., Bullard, D., Beaudet, A., and Kaplan, S.L. 1997. Host defense against systemic infection with Streptococcus pneumoniae is impaired in E-, P-, and E-/P-selectin-deficient mice. J. Clin. Invest. 100:2099-2106.

66. Meeusen, E., Lee, S., and Brandon, M. 1991. Differential migration of T and B cells during an acute inflammatory response. Eur. J. Immunol. 21:2269-2272. 